\title{
Influence of geologic structure on the presence, discharge and physical and chemical properties of springs in the Muszynka catchment (Carpathian flysch)
}

\author{
${ }^{1}$ Institute of Geological Sciences, Department of Hydrogeology, University of Wrocław, Pl. M. Borna 9, 50-204 Wrocław, Poland; \\ *Corresponding author, E-mail: sebastian.buczynski@uwr.edu.pl \\ ${ }^{2}$ Institute of Geography and Spatial Management, Department of Hydrology, Jagiellonian University, Ul. Gronostajowa 7, 30-387 Kraków, Poland
}

(Received: August 31, 2017; Revised accepted: April 20, 2018)

http://dx.doi.org/10.18814/epiiugs/2018/018012

The study helped to determine the spatial distribution of springs, their discharge values as well as the physical and chemical parameters of their waters, as these depend on the exact lithology of the aquifers drained and on the distance from tectonic discontinuity zones and the direction these follow in the flysch rocks of the Beskid Sadecki Range. The occurrence of springs is most frequently related to region-wide faults or joints that run in the NE-SW or NW$S E$ direction. However, that the presence of discontinuity zones does not always increase the number of springs per unit area or their discharge values. It was the case for some lithostratigraphic units that in spite of rather high tectonic activity, both a low springs density index and low spring discharge were obtained from the study. The relationships between water temperature or $\mathrm{pH}$ and categorized orientation of the nearest lineament proved to be statistically significant. Thus, it has been unambiguously shown that, in the study area, being located on lineaments or in structural zones does not affect spring discharge, temperature, pH or the SEC of spring water, but relatively high correlation values was found in the case of relationships between pH or SEC and categorized geology.

\section{Introduction}

The flysch Carpathians is a region, where the number of springs per unit area is among the largest in Poland. However, it has been found that throughout the entire region, the springs density index (the number of springs per unit area) varies substantially from one lithostratigraphic unit to another (Ciężkowski et al., 2001). The fact that geologic structure has an impact on the water abundance of an area was pointed out on many occasions in discussions on research results regarding spring occurrence in mountain areas (Magowe and Carr, 1999; Manga, 1999; Wu et al., 2004). The above works mentioned cases of an increase in the discharge of springs located adjacent to major tectonic fault zones. Furthermore, Graniczny et al. (2007) pointed out that in the study area, structural zones, identified basing on the interpretation of a pattern of lineaments, represent some of the primary factors that determine the occurrence of mineral water springs. It is within these zones that groups of fracture springs and hillslope fracture springs are observed.

The observations described above served as the main reason for the analysis of the occurrence of springs in the Muszynka catchment in the Beskid Sądecki Range, a catchment composed of flysch rocks. The results of the analysis were summarized to reflect the effects of lithology and tectonics on the spatial distribution of springs, their discharge, temperature, $\mathrm{pH}$, and electrical conductivity of water. The research study was conducted based on the results of hydrogeologic surveys performed in 2006, which allowed to create a GIS database containing specific information on each studied outflow. A verifiable hypothesis assumes that the lithology and tectonics (tectonic activity) will have an impact on a springs density index. The hypothesis also assumes that the high tectonic activity area will be characterized by higher spring discharge and a significant correlation between temperature, $\mathrm{pH}$ and SEC, and the geologic features of the study area.

\section{Study Area}

The study area of $53.3 \mathrm{~km}^{2}$ (Fig. 1) encompasses the upstream part of the Muszynka River catchment. The studied catchment is located in southern Poland along the border with the Republic of Slovakia. The mean annual air temperature in the study area ranges from 4 to $6{ }^{\circ} \mathrm{C}$ depending on elevation. The spatial distribution of atmospheric precipitation is characterized by a gradual increase in monthly and annual totals as elevation increases. The mean annual precipitation total for the period 1993-2006 was $889 \mathrm{~mm}$. Monthly precipitation totals are highest from May through August with a maximum in July, when the precipitation total is an average of $137 \mathrm{~mm}$ and a minimum value for December (46 mm).

The study area is part of the Magura Nappe in the Polish Flysch Carpathians. It lies at the juncture of two geologic subunits built of the following middle and upper Eocene formations: Bystrzyca (Sądecka), 


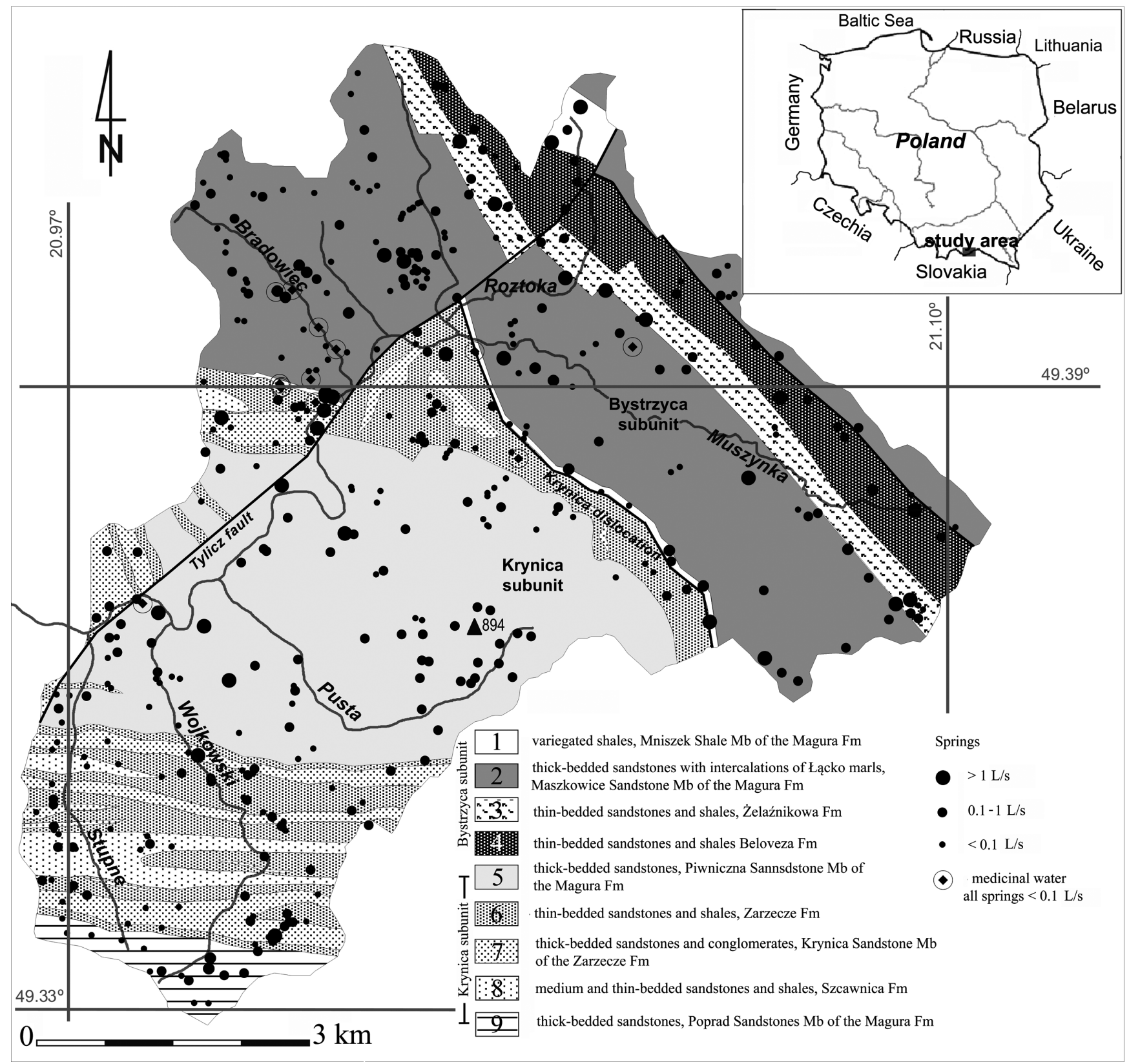

Figure 1. Geological map with springs locations.

Krynica (Fig. 1). The Bystrzyca subunit joins Krynica subunit formations along the line of a reverse fault (so-called Krynica dislocation), which dips towards NE. The Bystrzyca subunit is composed of sandstone (sometimes limy), shale, and marl, which belong to the Beloveża, Żeleźnikowa, and Magura formations. The Krynica subunit is composed of sediments of the Szczawnica, Zarzecze, and Magura formations present in the form of shale and thick-bedded, thin-bedded, and medium-bedded sandstone, as well as conglomerates (Oszczypko and Oszczypko-Clowes, 2010b) (Fig. 1).

Two major tectonic zones run across the study area and their presence is marked by tectonic faults that run in the east-west direction (Krynica dislocation) or run perpendicular to it (Tylicz dislocation) (Birkenmajer and Oszczypko, 1989). An analysis of lineaments confirms the pattern of the tectonic faults. Research furthermore indicates that tectonic high activity occurs in the study area (Doktór et al., 1985).
The study area is the site of the crossing of two regional zones: Muszyna-Nowy Sącz-Bochnia, which runs in the NW-SE direction, and Murań-Muszyna-Jasło, which runs in the NE-SW direction (Graniczny et al., 2007). The next group of lineaments is characterized by the fact that it runs in a direction that is close to the direction east-west; in the northern part changing course towards the ENE-WSW direction, and in the southern part towards the WNW-ESE direction (Fig. 2).

The flysch formation present in the study area does not form typical aquifers, and the occurrence of water is associated with weathered rocks and near-surface fracture zones (Margielewski, 2006). The groundwater content of a flysch series is determined by its sandstone members and the way they are formed and their degree of fracturing and porosity (Nałęcki et al., 2004). In addition to regular freshwater, the study area also yields waters considered to be medicinal. Springs with medicinal water contain various levels of carbon dioxide from 


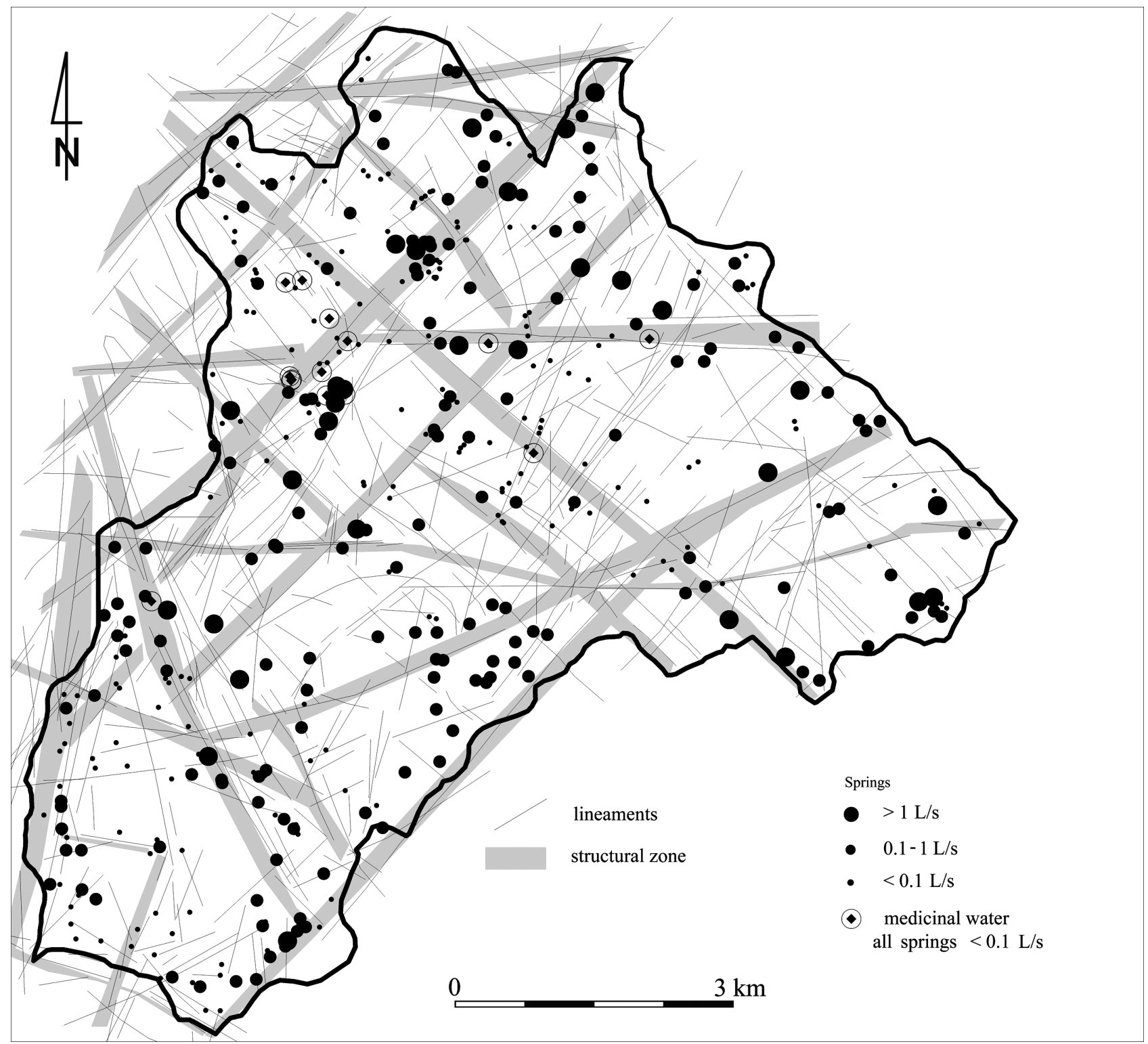

Figure 2. Map of the lineaments, structural zones and springs.

$352 \mathrm{mg} / \mathrm{L}$ to almost $3 \mathrm{~g} / \mathrm{L}$, with $\mathrm{pH}$ ranging from acidic to weakly alkaline (4.1-7.3), and water temperature ranging from 6.1 to more than $15^{\circ} \mathrm{C}$ (Zuber and Chowaniec, 2009; Rajchel, 2012; Buczyński et al., 2017).

\section{Material and Methods}

Information on the location of springs, their discharge, $\mathrm{pH}$, conductivity (SEC), and temperature is based on hydrologic surveys performed from May until September 2006. Spring locations, lithologic units and tectonic faults were digitized in a vector layer produced in ArcGIS software (Fig. 1). Geological Map by Oszczypko and Oszczypko-Clowes (2010a) was used as a source. The pattern of lineaments and structural zones (Fig. 2) was drawn using work by Graniczny et al. (2007).

An analysis of the spatial distribution of springs was performed using GIS software tools. The analysis included the recognition of dif- ferences in the spatial distribution of the springs density index, average and total spring discharge, total spring output rate and tectonic activity of the area understood as the length of lineaments per unit (Jarosiński, 2006; Buczyński and Rzonca, 2011). The number of springs was also analyzed, as it depended on the distance from lineaments, length of lineaments and the spatial orientation of lineaments. The analysis was conducted for the entire study area as well as for particular lithostratigraphic units.

Moreover, statistical methods were used in this study in order to verify whether there exists a relationship between the discharge of a spring and the very fact that it occurs within a particular lithostratigraphic unit. It was also verified whether spring discharge, temperature, $\mathrm{pH}$, and SEC depend on spring location - on a lineament or within a structural zone. It was also checked if spring discharge depends on the physical distance from a lineament and geographic orientation of the studied lineaments.

In the dataset produced in this study, in addition to recording field 
values of spring discharge, temperature, $\mathrm{pH}$ and SEC, particular springs were ascribed attributes categorizing the location of springs. Lithostratigraphic units were ascribed numeric symbols from 1 to 9 , which were used in the legend in Figure 1 and in the headings of Tables 2-5.

The location of a spring on a lineament or in a structural zone was described using two independent attributes in a "true-false" system: 1 - "true" (given spring is located on a lineament or in a structural zone) or 2 - "false" (is not located). Taking into account errors in GPS receiver readings and errors and uncertainties that may occur in the process of the creation of digital maps (Chrisman, 1991), an assumption was made that if a given spring was within a distance of 50 meters or less from a lineament, then the spring was treated as lying on a lineament ("true"). An additional attribute was introduced into the database, which describes the distance of a spring from the nearest lineament (with values of 1 to 4), where 1 stands for distances of less than $50 \mathrm{~m}, 2$ stands for 50-100 m, 3 stands for 100-150 m, and 4 stands for distances greater than $150 \mathrm{~m}$. Distances were measured and groups were created using the "summarize nearby" tool.

What was also recorded in the database was the categorized length of the lineament that is closest to a given spring; with the following values accepted to classify this attribute: up to $1,000 \mathrm{~m}, 1,001-2,000 \mathrm{~m}$, over 2,000 m. The "length" tool was then used to measure the length of lineaments. An attribute was also introduced categorizing the orientation (direction) of the lineament that is nearest to a given spring. Each lineament was ascribed real values of its course using the "getAzimuth" tool (ArcGIS). Next, the pattern of lineaments was generalized by classifying them into six groups $\left(0-30^{\circ}, 30-60^{\circ}, 60-90^{\circ}, 90-120^{\circ}\right.$, $\left.120-150^{\circ}, 150-180^{\circ}\right)$.

The dependence of the basic parameters of a given spring (discharge, and temperature, $\mathrm{pH}, \mathrm{SEC}$ ) on its categorized geologic unit, categorized distance from the nearest lineament, categorized orientation of the nearest lineament, and the categorized length of the nearest lineament was verified via correlation analysis. Some of the studied populations of values were not characterized by normal distributions, as verified using the Shapiro-Wilk statistical test (at the significance level $p<0.05$ ). In many cases, these distributions cannot be normalized by applying generally used methods. In cases when distributions of the compared characteristics are normal or can be normalized, the use of the standard parametric Pearson's correlation test is possible. The remaining cases, which cannot be analyzed via Pearson's test, as they do not satisfy the condition of normality of distribution, are a problem, and these cases constitute a majority. For this reason, analyses of all the correlation relationships in this study were consistently performed using the non-parametric Spearman's rank correlation test, and always at the significance level $p<0.05$. Spearman's rank correlation coefficient (denoted $r_{S}$ ) is interpreted in the same way as the most frequently used Pearson's correlation coefficient $r$, which means that it accepts values ranging from -1 to 1 , where -1 stands for full negative correlation (reverse), zero - for no correlation, and 1 - for full positive correlation.

In order to determine whether the fact of the occurrence of a spring on a lineament produces an effect on its basic parameters (discharge, and temperature, $\mathrm{pH}$, electrical conductivity of water), it was checked whether populations of values of the said parameters for springs located on a lineament and not located on a lineament are different in the statistical sense. For example, the population of spring discharge values must be divided into two subgroups (subpopulations): discharge values for springs located on a lineament and discharge values for springs not located on a lineament. Next, it must be investigated if there exists a statistically significant difference between these subpopulations, which is a typical use for statistical tests of similarity. The tested sub-populations of values (discharge, and temperature, $\mathrm{pH}$, electrical conductivity of water) were not characterized by normal distributions, according to the Shapiro-Wilk test, $p<0.05$, and cannot be easily normalized. This is why in order to compare sets of values, two typical non-parametric tests were used: Mood's median test, Kruskal-Wallis one-way analysis of variance by ranks. In both tests, it is assumed that the sub-populations being compared are alike (null hypothesis), while the significance level assumed was $p<0.05$. A similar set of tests was used to verify whether the fact of the occurrence of a spring in a structural zone produces an effect on its basic parameters (Jensen et al., 1997; Sobczyk, 2004). Statistical analyses were performed using Statigraphics Centurion XVI software.

Although mineral springs found in the study area stand out in terms of their mineral content, such springs were not identified for analysis as a separate group. Their share comprises just $3 \%$ of the population of springs, and detailed characteristics of their occurrence and regime variability were described in a separate paper (Buczyński et al., 2017).

\section{Results}

Hydrologic survey work performed in the study area identified 408 springs (Table 1, Fig. 1). Spring discharge measurement results show that $33.3 \%$ (136 springs) of the springs had discharge values in the range from 0.1 to $1 \mathrm{~L} / \mathrm{s}$. Only $6.9 \%$ (28 springs) of the springs had discharge values above $1 \mathrm{~L} / \mathrm{s}$. The most numerous group of springs (59.8\%) were outflows with discharge values of less than $0.1 \mathrm{~L} / \mathrm{s}$ (Table 1). The largest spring, which is located on the southwestern slope of Łan Mountain, had a discharge value of $5 \mathrm{~L} / \mathrm{s}$. Total discharge for all the studied springs was $115.2 \mathrm{~L} / \mathrm{s}$, which translates into a specific spring runoff (defined as the total discharge of all springs in a drainage basin divided by the area of the drainage basin) value of $2.16 \mathrm{~L} / \mathrm{s} / \mathrm{km}^{2}$.

Spring water temperature at the point of outflow reached values ranging from 6.1 to $13{ }^{\circ} \mathrm{C}, \mathrm{pH}$ was in the range from 5.3 to 8.2 , and specific

\section{Table 1. Classification of the springs}

\begin{tabular}{ccccc}
\hline Discharge rate [L/s] & Number of springs & Share in total number of springs [\%] & Total springs discharge [L/s] & Share in total springs discharge [\%] \\
\hline $1-10$ & 28 & 6.9 & 51.6 & 44.8 \\
$0.1-1$ & 136 & 33.3 & 53.2 & 46.2 \\
$<0.1$ & 244 & 59.8 & 10.3 & 9.0 \\
\hline TOTAL: & 408 & & 115.2 & \\
\hline
\end{tabular}


Table 2. Comparison of spring characteristics and tectonic activity of the study area and within individual parts of it

\begin{tabular}{lccccccccccc}
\hline & $\begin{array}{c}\text { Lithostratigraphic } \\
\text { units } \rightarrow\end{array}$ & 1 & 2 & 3 & 4 & 5 & 6 & 7 & 8 & 9 \\
& 53.28 & 0.63 & 17.16 & 2.57 & 3.67 & 15.03 & 7.78 & 3.63 & 1.47 & 1.34 \\
Area [A] $\left(\mathrm{km}^{2}\right)$ & 408 & 13 & 140 & 17 & 18 & 90 & 64 & 40 & 10 & 16 \\
Number of springs & 7.66 & 20.63 & 8.16 & 6.61 & 4.90 & 5.99 & 8.23 & 11.02 & 6.80 & 11.94 \\
Springs density index & 348.58 & 5.65 & 114.85 & 15.63 & 21.73 & 114.48 & 41.13 & 18.53 & 7.63 & 8.98 \\
Lineament length [1] (km) & 6.54 & 8.97 & 6.69 & 6.08 & 5.92 & 7.62 & 5.29 & 5.10 & 5.19 & 6.70 \\
Tectonic activity [1/A] & 0.27 & 0.68 & 0.23 & 0.58 & 0.46 & 0.27 & 0.21 & 0.31 & 0.10 & 0.14 \\
Average spring discharge (L/s) & 115.23 & 9.50 & 33.54 & 9.86 & 8.36 & 24.27 & 14.37 & 12.22 & 0.95 & 2.16 \\
Total spring output rate (L/s) & 2.16 & 15.08 & 1.95 & 3.84 & 2.28 & 1.61 & 1.85 & 3.37 & 0.65 & 1.61 \\
Specific spring runoff $\left(\mathrm{L} / \mathrm{s} / \mathrm{km}^{2}\right)$ & & & & & & & & &
\end{tabular}

Shaded values are above the average.

electrical conductivity (SEC) ranged from 0.03 to $2.79 \mathrm{mS} / \mathrm{cm}$, whereas much higher values of SEC were recorded for a number of mineral water springs (mean: $1.42 \mathrm{mS} / \mathrm{cm}$ and median: $1.37 \mathrm{mS} / \mathrm{cm}$ versus freshwater springs mean: $0.27 \mathrm{mS} / \mathrm{cm}$ and median: $0.29 \mathrm{mS} / \mathrm{cm}$ ).

The mean value of the springs density index for the entire study area was found to be 7.7 (Table 2). The value of the springs density index was similar in both subunits, and it was respectively 7.8 in the Bystrzyca subunit and 7.5 in the Krynica subunit. The lowest value of the springs density index (4.90) was noted for thin-bedded sandstone and loamy shale from the Beloveża formation (Unit 4 - Table 2), while the highest (20.63) was calculated for the variegated shale member of the Magura formation (Unit 1). The occurrence of numerous, high-discharge springs across Unit 1 was connected with the smallest geographic area of the unit $\left(0.63 \mathrm{~km}^{2}\right)$ as well as with the very close proximity of a tectonic fault called the "Krynica dislocation," which may be still seismically active (Oszczypko et al., 1999).

Tectonic activity of the catchment for each given lithostratigraphic unit, expressed as the ratio of the length of lineaments to the number of $\mathrm{km}^{2}$ of the partial catchment (1/A), was found to range from 5.10 to 8.97 (mean: 6.54). The value describing tectonic activity in the study area was larger for the Bystrzyca subunit (6.9) than for the Krynica subunit (6.0). The highest tectonic activity was found to be present in the case of variegated shale, in the Mniszek variegated shale member of the Magura formation in the Bystrzyca subunit (Unit 1 - Table 2). The Mniszek member was also characterized by the highest springs density index and specific spring runoff, which exceeded $15.08 \mathrm{~L} / \mathrm{s} / \mathrm{km}^{2}$, with the average being $2.16 \mathrm{~L} / \mathrm{s} / \mathrm{km}^{2}$ (Table 2).

The value of tectonic activity was also higher than average for units 5, 9, and 2 (Table 2, Fig. 1). All three units have a share of tectonic "discontinuities," respectively: 114.48, 8.98 and $114.85 \mathrm{~km}$ of tectonic discontinuities/lineaments (Table 2), which is equivalent to 7,616 ,
6,700 and 6,690 $\mathrm{m}$ of "discontinuities" per $1 \mathrm{~km}^{2}$ of area. Middle and thin-bedded sandstone of the Szczawnica formation and thick-bedded sandstone of the Magura formation were also characterized by above average values of the springs density index at 11.94 and 8.16, respectively. An exception was Unit 5, which in spite of its high tectonic activity (7.62) had a relatively low specific spring runoff index (1.61) and a low springs density index (5.99). Additionally, two units (6 and 7) featuring low tectonic activity (5.10 to 5.29) were characterized by an above average value of the springs density index ( 8.23 to 11.02).

The average discharge of springs in the Bystrzyca subunit was found to be 0.49 , while in the Krynica subunit, it was $0.2 \mathrm{~L} / \mathrm{s}$. The highest average discharge values for springs and seeps were calculated for three units in the Bystrzyca subunit (1, 3, and 4 - Table 2). Similar results were obtained in the case of the specific spring runoff index, where for the Bystrzyca subunit, its value was $5.79 \mathrm{~L} / \mathrm{s} / \mathrm{km}^{2}$, while for the Krynica subunit, it was only $1.82 \mathrm{~L} / \mathrm{s} / \mathrm{km}^{2}$.

An analysis of the distance of springs from the nearest discontinuity zones shows that most springs (77.9\%) are located within $50 \mathrm{~m}$ from discontinuity zones (Table 3 ). The number of springs rapidly decreases with distance from a discontinuity. The distance interval of 50 to 100 meters from a lineament is associated with $14.7 \%$ of springs, with $5.9 \%$ in the distance interval of 100 to $150 \mathrm{~m}$, and $1.5 \%$ over 150 meters (Table 3).

The analysis of the distribution of the number of outflows, as it depends on the length of discontinuity zones, also indicates that the highest number of springs and seeps occur near the longest discontinuities, exceeding 2,000 $\mathrm{m}$ in length (52.5\%). Springs found in the thin-bedded sandstone of Żeleźnikowa slightly diverge from this trend, as here a greater number of outflows occur at discontinuity zones up to $2,000 \mathrm{~m}$ in length. A different picture is presented in the case of two

Table 3. Distributions of the number of springs with respect to the distance from discontinuity zones

\begin{tabular}{ccccccccccccc}
\hline $\begin{array}{c}\text { Distance from } \\
\text { discontinuity zones [m] }\end{array}$ & $\begin{array}{c}\text { Lithostratigraphic } \\
\text { units } \rightarrow\end{array}$ & 1 & 2 & 3 & 4 & 5 & 6 & 7 & 8 & 9 \\
\hline$<50$ & 318 & 12 & 111 & 10 & 14 & 70 & 49 & 33 & 8 \\
$50-100$ & 60 & 1 & 20 & 4 & 3 & 10 & 9 & 6 & 2 & 5 \\
$100-150$ & 24 & 0 & 8 & 3 & 1 & 8 & 4 & 0 & 0 & 0 \\
$>150$ & 6 & 0 & 1 & 0 & 0 & 2 & 2 & 1 & 0 & 0 \\
\hline
\end{tabular}


Table 4. Distributions of the number of springs with respect to the length of discontinuity zones

\begin{tabular}{cccccccccccc}
\hline $\begin{array}{c}\text { Length of discontinuity } \\
\text { zones [m] }\end{array}$ & $\begin{array}{c}\text { Lithostratigraphic } \\
\text { units } \rightarrow\end{array}$ & 1 & 2 & 3 & 4 & 5 & 6 & 7 & 8 & 9 \\
\hline$<1000$ & 136 & 3 & 43 & 6 & 4 & 27 & 19 & 14 & 8 & 12 \\
$1000-2000$ & 58 & 1 & 16 & 6 & 6 & 14 & 7 & 5 & 1 & 2 \\
$>2000$ & 214 & 9 & 81 & 5 & 8 & 49 & 38 & 21 & 1 & 2 \\
\hline
\end{tabular}

Table 5. Distribution of the number of springs with respect to the orientation of discontinuity zones

\begin{tabular}{ccccccccccc}
\hline $\begin{array}{c}\text { Orientation of discontinuity } \\
\text { zones }\end{array}$ & $\begin{array}{c}\text { Lithostratigraphic } \\
\text { units } \rightarrow\end{array}$ & 1 & 2 & 3 & 4 & 5 & 6 & 7 & 8 & 9 \\
\hline NNW-SSE 0-30 & 28 & 0 & 5 & 3 & 0 & 9 & 5 & 5 & 1 & 0 \\
NW-SE 30-60 & 89 & 5 & 41 & 1 & 6 & 18 & 13 & 5 & 0 & 0 \\
ESE-WNW 60-90 & 44 & 0 & 8 & 2 & 2 & 9 & 8 & 5 & 3 & 7 \\
ENE-WSW 90-120 & 44 & 0 & 10 & 6 & 5 & 7 & 8 & 2 & 3 & 3 \\
NE-SW 120-150 & 149 & 5 & 64 & 5 & 4 & 29 & 23 & 16 & 0 & 3 \\
NNE-SSW 150-180 & 54 & 3 & 12 & 0 & 1 & 18 & 7 & 7 & 3 & 3 \\
\hline
\end{tabular}

units in the Krynica subunit. In the case of units 8 and 9, the highest number of springs was found at discontinuity zones not exceeding 1,000 meters in length (Table 4).

The location of springs with respect to the orientation of discontinuity zones indicates that the highest number of "water occurrences" correlate with zones that run in the NE-SW direction (Murań-MuszynaJasło), and then with fractures that run in the NW-SE direction or in the NNE-SSW direction. When divided into fracture-orientation groups, $36.5 \%$ of springs are associated with fractures that run in the NE-SW direction, $21.8 \%$ are associated with the NW-SE fracture orientation, and $13.2 \%$ with the NNE-SSW fracture orientation (Table 5).

Another aims of this study was to consider the question whether there does exist a relationship between spring discharge, temperature, $\mathrm{pH}$ and SEC, and the local geological features of the study area. The correlation analysis that was performed (using Spearman's rank method) for every listed parameter and categorized geologic unit, distance from the nearest lineament, orientation of the nearest lineament, as well as the length of the nearest lineament, produced the following results (correlations that were not statistically significant were omitted). The correlation values are relatively high in the case of relationships between $\mathrm{pH}$ or SEC and categorized geology $\left(r_{S}=0.39\right.$ and $r_{S}=$ 0.29 , respectively). The relationships between water temperature or $\mathrm{pH}$ and categorized orientation of the nearest lineament $\left(r_{S}=0.13, r_{S}\right.$ $=0.17$, respectively) proved to be statistically significant, yet weak and difficult to interpret for this very reason.

An important matter in this study was the effect of spring sites found on a lineament or in a structural zone on the hydrologic and hydrochemical parameters of the water. However, according to both applied statistical tests (Mood and Kruskal-Wallis) neither being located on a lineament (or not), nor being located in a structural zone (or not) makes the studied set of parameter values different in a way that would be statistically significant. Thus, it has been unambiguously shown that, in the study area, being located on lineaments or in structural zones does not affect spring discharge, temperature, $\mathrm{pH}$ or the SEC of spring water.

\section{Discussion}

The flysch Carpathians are a region characterized by the highest springs density index in Poland (Chełmicki et al., 2011). At the same time, this study has also shown that values of the springs density index, in the studied flysch areas in Poland, can vary substantially (Ciężkowski et al., 2001). The springs density index for the Barania Góra Range was found to be more than 37, according to Pazdro and Kozerski (1990). In the Połonina Wetlińska grassland in the Bieszczady Range, Mocior et al. (2015) found that the springs density index was even higher (47.98). Research in the Polish part of the Poprad river catchment (Koślacz, 2014) produced an average "springs density index" value for an area of $395 \mathrm{~km}^{2}$ of 6.80 , ranging from 3.28 for the Poprad-Barcice water balance area to 18.48 for the Mochnaczka water balance area; thus, confirming the hypothesis of a large number of springs in the area. In close proximity of the study area (Kryniczanka catchment), Ciężkowski et al. (2001) found differences between lithostratigraphic units in terms of the value of the springs density index, which varied in the range from 4.8 to 50.0. The highest value of the springs density index was typical for conglomerates found within the sandstone member of Piwniczna in the Krynica subunit. A relatively high value of the springs density index (over 20) was also characteristic of rocks of the Szczawnica formation. The values of the springs density index for the thickbedded sandstone of the member from Maszkowice in the Bystrzyca subunit and the sandstone member of Piwniczna found in the Krynica subunit resembled each other: 10.8 and 9.9, respectively. In the upper Muszynka catchment, differences in the springs density index were not as large. The springs density index for particular lithostratigraphic units varied in the interval from 4.9 to 20.6. In contrast to results obtained by Ciężkowski et al. (2001), the sandstone member of Piwniczna was characterized by a value of the springs density index that was almost two times less and the rocks of the Szczawnica formation - almost three times less. Similar "springs density" was typical for the sandstone member from Maszkowice in the Bystrzyca subunit (8.16) and the sand- 
stone and shale of Zarzecze in the Krynica subunit (8.23).

In terms of discharge, springs and seeps in flysch rocks are low output outflows. In the Kryniczanka catchment (Ciężkowski et al., 2001), more than $90 \%$ of springs and seeps are in the $7^{\text {th }}$ and $8^{\text {th }}$ discharge classes on the Mainzer scale, while in the Poprad catchment, $68.6 \%$ of outflows were found to have discharge values below $0.1 \mathrm{~L} / \mathrm{s}$ (Koślacz, 2014). In the upper Muszynka catchment, the percentage of outflows with discharge below $0.1 \mathrm{~L} / \mathrm{s}$ was smaller at less than $60 \%$. Świdziński (1972) studied outflows in flysch rock areas and found that fissure springs yield the highest output. Also in the Muszynka catchment, highest discharge values characterize the springs and seeps found across the most tectonically active lithostratigraphic unit (unit 1). This relationship did not always hold in the case of other units, which may indicate a lack or restricted movement of water through a tectonic discontinuity in units 5 and 2. Both in the Kryniczanka catchment (Ciężkowski et al., 2001) as well as in the Upper Muszynka catchment, the lowest discharge values were characteristic of outflows in the Szczawnica formation, which confirmed the low water-bearing capacity of the rocks of this formation.

Additionally, Ciężkowski et al. (1999) showed that local geology has a significant influence on the magnitude of groundwater flow and that the water-bearing capacity of the rocks of the Saqdecka subunit is higher in comparison with the water-bearing capacity of rocks in the Krynica subunit. These findings were obtained based on measurements of flow in streams at low flow and confirm the observations of the magnitude of specific spring runoff in the upper Muszynka catchment. In this case, the specific spring runoff values are higher for the rocks of the Bystrzyca subunit $\left(5.75 \mathrm{~L} / \mathrm{s} / \mathrm{km}^{2}\right)$ than for the rocks of the Krynica subunit $\left(1.82 \mathrm{~L} / \mathrm{s} / \mathrm{km}^{2}\right)$.

The observation made in the field that the number of springs increases as one gets near tectonic discontinuity zones is in agreement with findings available in the literature, that in the zones of large tectonic shifts (faults), there are always springs, seeps, and wetlands, and that an increase in the density of rock fracturing due to tectonic activity makes it easier for water to migrate towards the Earth's surface (Pacheco and Alencoão, 2002). Ciężkowski et al. (2001) detected visible linear outflows and wetlands in close proximity to the study area associated with the pattern of the "Krynica dislocation" on the Jaworzynka slopes. In the Muszynka catchment, the highest springs density index and specific spring runoff index associated with variegated Mniszek shale are also associated with the nearby "Krynica dislocation" (Fig. 2), which is notable for numerous high discharge springs in its immediate vicinity.

An analysis of a single structural parameter (e.g., fracture density) would not yield accurate results. Pacheco and Alencoão (2002) were able to show that the number of springs found per one kilometer of lineament $(\mathrm{Nk})$ depends primarily on the type, age, and regime of the given deformation. Similarly, there exist lithostratigraphic units in the Upper Muszynka catchment characterized by high tectonic activity; however, a large number of discontinuities does not translate into a high value of the springs density index or increased discharge values for springs and seeps. Jarosiński (2006) and the World Stress Map Project (http://dc-app3-14.gfz-potsdam.de/) both show that a number of stress factors originating from many directions converge in Poland. The area of the Carpathians is characterized by the fact that the lineament pattern changes directions frequently, and the directions that do dominate are: NW-SE, NE-SW and N-S (Graniczny et al., 2007). The orientations correspond to the directions of the regional zones, which intersect in this region, namely the Muszyna-Nowy Sącz-Bochnia zone (NW-SE) and the Murań-Muszyna-Jasło zone (NE-SW). Research has shown that most frequently springs are associated with lineaments having these orientations. Therefore, it may be regarded as highly likely that the occurrence of springs is most often associated with regionwide joints that run in the NE-SW or NW-SE directions.

\section{Conclusions}

Springs found in the upper Muszynka catchment, just like springs found in all other flysch areas in Poland, are mostly springs with discharge values below $0.1 \mathrm{~L} / \mathrm{s}$. The tectonic activity of the underlying area has a significant influence on their occurrence for most of the water occurrences are located within a distance of up to $50 \mathrm{~m}$ from a geologic discontinuity. However, statistical research has shown that the location of a spring on a lineament or in a structural zone does not affect the discharge of springs and seeps and does not affect major parameters such as temperature, $\mathrm{pH}$, and the SEC of spring waters.

Most occurrences of springs are associated with tectonic discontinuities/lineaments that run in the NE-SW or NW-SE directions. Groundwater flow through fissures is suggested by the fact that from the point of view of contemporary geodynamics, the area is characterized by a relative stability of directions of the highest present-day horizontal stress. In several cases, the lithostratigraphic units with the highest tectonic activity were at the same time characterized by the highest average discharge of outflows and by the highest specific spring runoff index. However, research results obtained through this form of reasoning did not always provide unambiguous answers, which suggests that a number of discontinuities are not passable to groundwater in the sense of free flow, and these zones do not qualify as areas of spring drainage.

The research confirmed substantial differences in the value of the springs density index in areas composed of flysch rocks. In the study area, the research results also point to the small water-bearing capacity of the Szczawnica formation. At the same time, research has shown that the sandstone members of Piwniczna, depending on the examined area, are characterized by high variability of the springs density index. In this study, analysis of water abundance, spring discharge, and the specific spring runoff index also indicates that the water-bearing capacity of the rocks of the Bystrzyca subunit is larger than that of the rocks of the Krynica subunit.

\section{Acknowledgements}

We wish to thank the Reviewers and Co-editor for their detailed comments, which were very valuable in the editing process and in our understanding of relevant influence of geologic structure on the presence, discharge and physical and chemical properties of springs. Suggestions made by the reviewers were very helpful in the process of eliminating errors and imperfections in the first version. This study was carried out under Research Grant No. 0401/0163/2017 given by Poland's Ministry of Science and Higher Education. 


\section{References}

Birkenmajer, K., and Oszczypko, N., 1989, Cretaceous and Palaeogene lithostratigraphic units of the Magura Nappe, Krynica subunit, Carpathians. Annales Societatis Geologorum Poloniae, v. 59, pp. 145-181.

Buczyński, S., Modelska, M., and Wcisło, W., 2017, Występowanie i reżim źródeł szczaw i wód kwasowęglowych w zlewni górnej Muszynki (Occurrence and regimes of carbonated waters and carbonic acid water in the upper Muszynka River basin). Przegląd Geologiczny, v. 65, pp. 23-31.

Buczyński, S., and Rzonca, B., 2011, Effects of crystalline massif tectonics on groundwater origin and catchment size of a large spring area in Zieleniec, Sudety Mts., SW Poland. Hydrogeology Journal, v. 19, pp. 1085-1101.

Chełmicki, W., Jokiel, P., Michalczyk, Z., and Moniewski, P., 2011, Distribution, discharge and regional characteristics of springs in Poland. Episodes, v. 34, pp. 244-256.

Chrisman, N.R., 1991, The error component in spatial data. In: Maguire, D.J., Goodchild, M.F., and Rhind, D.W. (Eds.), Geographical Information Systems: Overview Principles and Applications. Longmans, Essex, v. 2 , pp. $165-174$

Ciężkowski, W., Kozłowski, J., Liber-Madziarz, E., Przylibski, T.A., and Żak, S., 1999, Zróżnicowanie modułu odpływu podziemnego w zlewni Kryniczanki w okresie niżówkowym (Specific underground runoff diversification in Kryniczanka river basin during low groundwater flow period). Przegląd Geologiczny, v. 47, pp. 564-566.

Ciężkowski, W., Schmalz, A., and Żak, S., 2001, Charakterystyka krenologiczna zlewni Kryniczanki w Beskidzie Sądeckim (Spring's characteristic of the Kryniczanka River catchment, Beskid Sadecki Mts (Carpathian)). Współczesne Problemy Hydrogeologii, v. 10, pp. 141-148.

Doktór, S., Dornic, J., Graniczny, M., and Reichwalder, P., 1985, Structural elements of Western Carpathians and their Foredeep on the basis of satellite interpretation. Kwartalnik Geologiczny, v. 29, pp. 129-137.

Graniczny, M., Piątkowska, A., and Kowalski, Z., 2007, Elaboration of the Lineament (Photolineament) Map of the "Tylicz I" Mining Area. Hydrokonos, Warszawa, $16 \mathrm{p}$

Jarosiński, M., 2006, Recent tectonic stress field investigations in Poland: a state of the art. Geological Quarterly, v. 50, pp. 303-321.

Jensen, J.L., Lake, L.W., Corbett, P.W.M., and Goggin, D.J., 1997, Statistics for Petroleum Engineers and Geoscientists. Prentice-Hall, Upper Saddle River, $362 p$

Koślacz, R. (Ed.), 2014, Hydrogeological Documentation Establishing the Safe Yield Groundwater in the Balance Areas of Co-medicinal Waters and Fresh Groundwater in a Separate Area of the Carpathian-Poprad River Catchment. Integrated Management Services, Wrocław, 199 p.

Magowe, M., and Carr, J.R., 1999, Relationship between lineaments and ground water occurrence in western Botswana. Ground Water, v. 37, pp. 282-286.

Manga, M., 1999, On the timescales characterizing groundwater discharge at springs. Journal of Hydrology, v. 219, pp. 56-69.

Margielewski, W., 2006, Structural control and types of movements of rock mass in anisotropic rocks: case studiem in the Polish Flysch Carpathians. Geomorphology, v. 77, pp. 47-68.

Mocior, E., Rzonca, B., Siwek, J., Plenzler, J., Płaczkowska, E., Dąbek, N., Jaśkowiec, B., Potoniec, P., Roman, S., and Zdziebko, D., 2015, Determinants of the distribution of springs in the upper part of a flysch ridge in the Bieszczady Mountains in southeastern Poland. Episodes, v. 38, pp. 21-30.

Nałęcki, P., Reśko, D., Schmalz, A., and Witczak, S., 2004, Charakterystyka parametrów hydrogeologicznych szczelinowo-porowego złoża wód leczniczych w Krynicy (Hydrogeological parameters description of fissured-porous therapeutic groundwater basin in Krynica). Biuletyn Państwowego Instytutu Geologicznego, v. 404, pp. 144-164.

Oszczypko, N., Malata, E., Oszczypko-Clowes, M., and Duńczyk L., 1999,
Budowa geologiczna Krynicy (płaszczowina magurska) (Geological characterisation of the Krynica Subunit (Magura Nappe)). Przegląd Geologiczny, v. 47, pp. 549-559.

Oszczypko, N., and Oszczypko-Clowes, M., 2010a, Budowa geologiczna okolic Krynicy-Zdroju i Muszyny (SE części Beskidu Sądeckiego, Zewnętrzne Karpaty Zachodnie) (Geological characterisation of the Krynica-Zdroj and Muszyna area (SE part of Beskid Sądecki, Outer Western Carpathians)). P.B.G “Geoprofil”, Kraków.

Oszczypko, N., and Oszczypko-Clowes, M., 2010b, The Paleogene and nearly Neogene stratigraphy of the Beskid Sądecki Range and Lubovnianska Vrchovina (Magura Nappe Western Outer Carpathians). Acta Geologica Polonica, v. 60, pp. 317-348.

Pacheco, F.A.L., and Alencoão, A.M.P., 2002, Occurrence of springs in massifs of crystalline rocks, northern Portugal. Hydrogeology Journal, v. 10, pp. 239-253.

Pazdro, Z., and Kozerski, B., 1990, Hydrogeologia Ogólna (Basics of Hydrogeology). Wydawnictwa Geologiczne, Warszawa, 624 p.

Rajchel, L., 2012, Szczawy i Wody Kwasoweglowe Karpat Polskich (Carbonated Waters and Waters Containing Carbon Dioxide of the Polish Carpathians). Wydawnictwa Akademii Górniczo-Hutniczej, Kraków, $194 \mathrm{p}$.

Sobczyk, M., 2004, Statystyka (Statistics). Polskie Wydawnictwo Naukowe, Warszawa, $428 \mathrm{p}$.

Świdziński, H., 1972, Geologia i Wody Mineralne Krynicy (Geology and Mineral Waters of Krynica): Prace Geologiczne - Polska Akademia Nauk. Oddział w Krakowie, Komisja Nauk Geologicznych 70, Wydawnictwa Geologiczne, Warszawa, 104 p.

The World Stress Map Project, 2015, A Service for Earth System Management: http://dc-app3-14.gfz-potsdam.de/ [accessed 15.12.15].

Wu, Y., Liu, H.H., and Bodvarsson, G.S., 2004, A triple-continuum approach for modeling flow and transport processes in fractured rock. Journal of Contaminant Hydrology, v. 73, pp. 145-179.

Zuber, A., and Chowaniec, J., 2009, Diagenetic and other highly mineralized waters in the Polish Carpathians. Applied Geochemistry, v. 24, pp. 1889-1900.

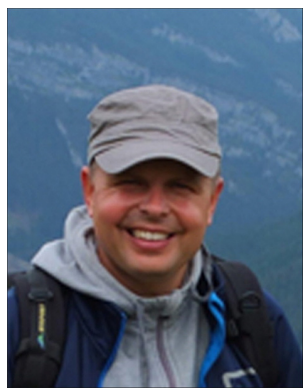

Sebastian Buczyński, Ph.D. is a hydrogeologist at the Faculty of Earth Sciences and Environmental Management, University of Wrocław. His main research area including hydrology of springs and the hydrogeology of heterogeneous rocks - hard rocks and karst formations. Recently, the research has been concentrated to the groundwater resources especially groundwater flow systems and the conditions of the formation of groundwater resources in crystalline and sedimentary rocks.

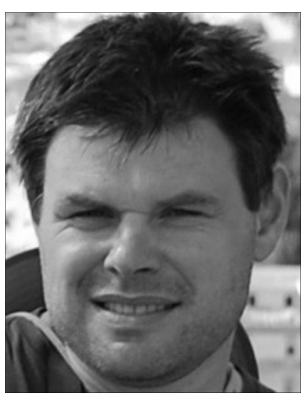

Bartlomiej Rzonca, Ph.D. is a hydrogeologist at the Jagiellonian University in Krakow, Department of Hydrology. His research interests involve two main subject areas: the broadly defined field of spring research and the hydrogeology of heterogeneous rocks (crystalline and karst). 